The 3rd International Conference on Biological Science 2013

(The 3rd ICBS-2013)

\title{
SEX DETERMINATION OF BALI STARLING (Leucopsar rothschildi) USING MOLECULAR SEXING
}

\author{
Putu Indra Pramana Wirastika', Ignatius Pramana Yuda², Felicia Zahida \\ Fakultas Teknobiologi Universitas Atma Jaya Yogyakarta, \\ Jl. Babarsari 44 Yogyakarta 55281, Indonesia \\ Email: 1) Nd_ra_21@yahoo.com; 2) pramyd@staff.uajy.ac.id
}

\begin{abstract}
Bali Starling (Leucopsar rothschildi) are monomorphic at the age of nestling. For the conservation of bird it important is to determine its sex at the earlier stage. Conventional methods have limitations. This study applied PCR-based molecular sexing to answer this issue. This study aimed to obtain the most effective molecular primers to identify the sex of Bali starling. The most common used combination of P2/P8, 2550F/ 2718R and 1237L/1272H primers, which amplify CHD1 gene (Chromo-helicase-DNA-binding) were evaluated. DNA samples were obtained from secondary wing feathers of young Bali Starling. Separation in agarose gel electrophoresis of PCR products showed that the three primers were successfully amplified the samples with different degrees of success, that was 90\% (P2/P8), 86.7\% (2550F/2718R), and 73.3\% (1237L/1272H), respectively. However, only the combination of P2/P4 and 2550F/2718R primers was able to sex Bali Starling based on observation of PCR products on agarose gel. The sizes of the genes were slightly different with those reported on previous studies. Most of the results of molecular sexing were in accordance with the sex based on morphological characters.
\end{abstract}

Key words : Bali starling, Leucopsar rothschildi, molecular sexing, CHD gene

\section{INTRODUCTION}

Bali Starling is an endemic bird to Bali Island, and due to its small population it has been classified by International Union for Conservation of Nature (IUCN) as Critically Endangered species (BirdLife International, 2013). A breeding program in Tegal Bunder has been initiated to increase the remaining population. Bali Starling is considered sexually monomorphic, particularly in young bird, so it is hard to determine an individual's sex without having the bird in hand. For nestling, however, it is very difficult to identify the sex by morphological examination.

The identification of sex is very important because it is one of keys points on Bali Starling breeding program. By using the knowledge of sex identification genes, the breeding program can be applied more successfully.

Some methods have been developed for sex identification of monomorphic birds, i.e., vent sexing, laparoscopy, sexing steroid and karyotyping. These methods, however, are less or unreliable, time-consuming and expensive. Even some of the methods can hurt or even kill the bird (Dubiec and M, 2006). The DNA-based molecular sexing provides a solution.

The sex of an individual is recognized from the genes located on sex chromosomes. Female birds have one copy of both $Z$ and $W$, and male birds have two copies of $Z$ avian sex chromosomes. There are many DNA techniques available, such as Griffiths et al. (1998) who amplified sex specific CHD1 gene by using P2 - P8 primer pairs, which was successful for 27 of the 28 tested bird species from across the class of Aves. Furthermore Fridolfssom and Ellegren (1999) used 2550F/2718R primer pairs to test the sex of non-ratite birds. This study tested 50 birds species from 11 orders and successfully sexing 47 of the species. 
Meanwhile 1237L/1272H primer pairs was used by Kahn et al.(1998). Those three combinations of primers are the most common primer sets which are used for molecular sexing. This study aims to assess the reliability of those tree primer set to identify the sex of Bali Starling.

\section{MATERIALS AND METHODS \\ Samples}

Materials for DNA samples were obtained from molted wing feathers (score 2), which were plucked from the young birds of breeding program in Bali Barat National Park. In total 30 samples were obtained from different individual young birds, which were sexually known based on its morphology were examined in this study. Each feather sample was stored in an envelope and then transferred into a $1.5 \mathrm{ml}$ centrifuge tube filled with Queen's Lysis buffer until sink, and then it was kept on the room temperature or refrigerator.

DNA extraction was done using terminal part of bird's feather $(0,5-1 \mathrm{~cm})$ then it was put into a centrifuge tube containing $500 \mathrm{ml}$ lysis buffer $(50 \mathrm{mM}$ Tris-HCL pH 8; $20 \mathrm{mM}$ ethylene diamine tetra acetic [EDTA], $2 \%$ sodium dodecyl sulfate [SDS]) and proteinase $\mathrm{K}$ with consistency amount of $175 \mathrm{mg} / \mathrm{ml}$. Afterwards, samples were incubated at $37^{\circ} \mathrm{C}$ for 24 hours. After 24 hours the temperature was increased to $50^{\circ} \mathrm{C}$ for 1 hour. After the lysis process, sample was centrifuged on $13000 \mathrm{rpm}$ for 10 minutes. DNA purification was done by phenol chloroform isoamylalcohol (PCI) with comparison of 25:24:1 (Bello, 2001).

\section{PCR analysis}

PCR amplifications were performed in Veriti®thermal cycler, in a $25 \mathrm{iL}$ volume. Each reaction using approximately $20 \mathrm{ng}$ of genomic DNA as template, primers P2/P8 at 0,3 mM each, $0,2 \mathrm{mM}$ each dNTP, $1,5 \mathrm{mM} \mathrm{MgCl}$, 3U Tag DNA polymerase, and 1x Tag Buffer. Meanwhile for the other two primers sets $(2550 \mathrm{~F} / 2718 \mathrm{R}$ and $1237 \mathrm{~L} / 1272 \mathrm{H})$, each reaction contained of primers at 0,2 mM each, 0,2 mM each dNTP, 1,5 mM MgCl, 2U Tag DNA polymerase, and $1 \times$ Tag Buffer. After a series of optimizing the reaction was reached, the PCR program used for the $\mathrm{P} 2 / \mathrm{P} 8$ primers was $94^{\circ} \mathrm{C}$ for 5 minutes, then 40 cycles of $94^{\circ} \mathrm{C}$ for 30 sec., $48^{\circ} \mathrm{C}$ for $45 \mathrm{sec}$., $72^{\circ} \mathrm{C}$ for $30 \mathrm{sec}$, followed by $72^{\circ} \mathrm{C}$ for $5 \mathrm{~min}$. Meanwhile for the $2500 \mathrm{~F} / 2718 \mathrm{R}$ primers the $\mathrm{PCR}$ conditions was $95^{\circ} \mathrm{C}$ for 5 minutes, then 35 cycles of $95^{\circ} \mathrm{C}$ for $30 \mathrm{sec}$., $42^{\circ} \mathrm{C}$ for $40 \mathrm{sec}$., $72^{\circ} \mathrm{C}$ for $30 \mathrm{sec}$, followed by $72^{\circ} \mathrm{C}$ for $5 \mathrm{~min}$; and for $1237 \mathrm{~L} /$ $1272 \mathrm{H}$ primers was $92^{\circ} \mathrm{C}$ for 2 minutes, then 30 cycles of $95^{\circ} \mathrm{C}$ for $30 \mathrm{sec} ., 57^{\circ} \mathrm{C}$ for $45 \mathrm{sec}$., $72^{\circ} \mathrm{C}$ for $45 \mathrm{sec}$, followed by $72^{\circ} \mathrm{C}$ for $5 \mathrm{~min}$.

DNA fragments obtained by PCR were separated in $3 \%$ gel agarose stained with SYBER $\circledast$ Safe, and was examined visually under UV light in KODAK Gel Logic 100 System.

\section{RESULTS AND DISCUSSION}

The band patterns of DNA fragment obtained by PCR for Bali Starling were showed in Figure 1. Female samples presented two bands, meanwhile male samples presented one band and smaller size, either for PCR using primer set 2550F/2718R (Figure1A) or P2/P8 (Figure 1C). However, the use of combination primer 1237L/1272H was not able to differentiate the male and female samples. All the samples which were amplified using the primer 
set $1237 / 1272 \mathrm{H}$ showed single band. Increasing the consentration of the agarose gel (4\%) showed the same results. This finding sugested the need to separate the amplicon on acrylimide gel. The same results were reported by Kahn et al. (1998) for seven bird species, that the female bird samples showed singgle band in agarose gel. However, two of them resolved two bands in acrylimide gel.

Amplification using primer set $2550 \mathrm{~F} / 2718 \mathrm{R}$ obtained the amplicon size of chromosome $Z$ of $679 \mathrm{bp}$ and the second was chromosome $W$ as $459 \mathrm{bp}$ (Figure 1A). These sizes were slightlydifferent compare to the finding reported by Dawson et al. (2001), using the primer to sex four species of auklet $(Z=600 ; W=430)$. In other had using primer set $P 2 / P 8$ obtained amplicon size from chromosome $\mathrm{W}=393 \mathrm{bp}$ and chromosomes $Z=351 \mathrm{bp}$ (Figure 1C). These sizes were in agreement with the study by Griffths et al. (1998). The single band of the fragment DNA which were amplified using the combination $1237 \mathrm{~L} / 1272 \mathrm{H}$ primers was $\sim 338$ bp (Figure 1B) was longer than the range size reported by Kahn et al. (1998).

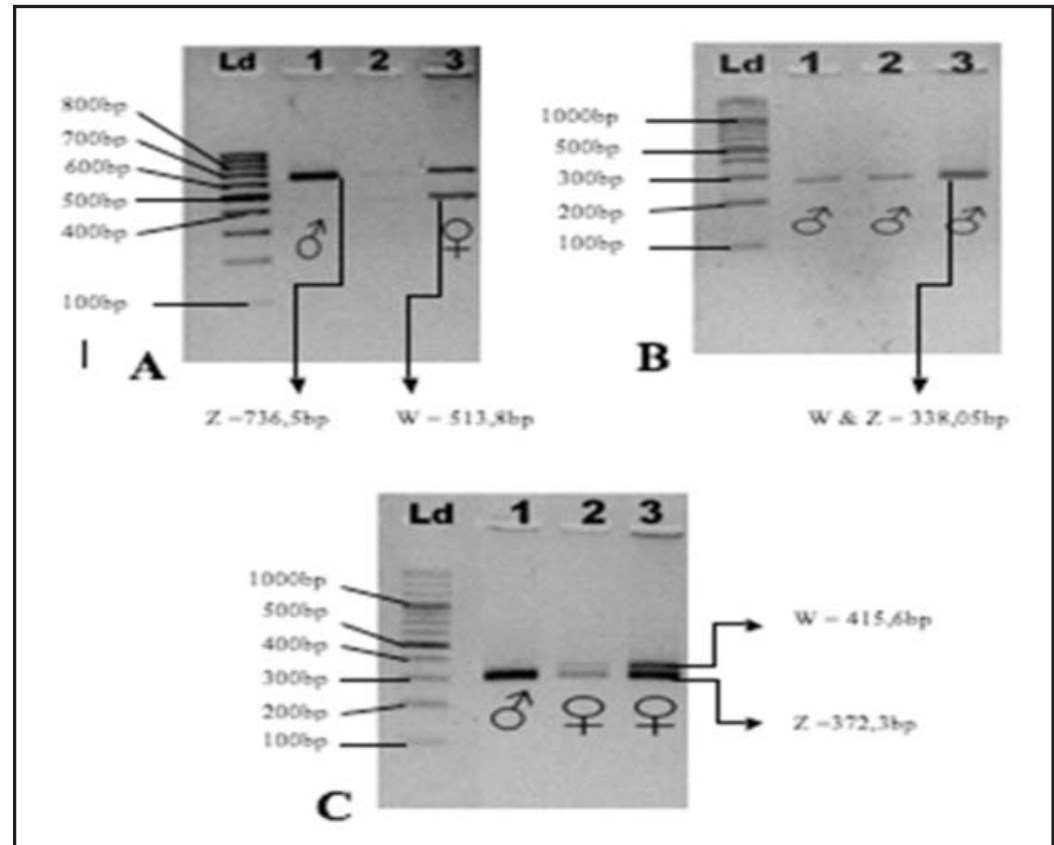

Figure 1. PCR amplifications of three different genotypes using the combination of (A) 2550F/ 2718R, (B) $1237 \mathrm{~L} / 1272 \mathrm{H}$, and (C) P2/P8 primers, run and imaged on a $3 \%$ gel and stained with SYBR Safe.

The PCR product suggested that the three common combinations of primers for molecular sexing have successfully amplified the chromosome sex of the Bali Starling. However, among the 30 samples assessed were not all been amplified. The success ratio were $90 \%, 86,7 \%$, and $73,3 \%$, respectively for the combination $\mathrm{P} 2 / \mathrm{P} 8,2550 \mathrm{~F} / 2718 \mathrm{R}$ and $1237 \mathrm{~L} / 1272 \mathrm{H}$ primers. Based on these ratios and the ability to differ the sex, male and female, the combination of P2/P8 primers was the most reliable primer to identify the sex of Bali Starling.

The sex of Bali Starling, which were tested using molecular test, either using combination of $2550 \mathrm{~F} / 2718 \mathrm{R}$ or P2/P8 primers, were identical for the positive samples (Table 1). However, not all of the results were in accordance with the sex determination based on its morphology. Six samples were identified differently, suggested that there was possibility a mistake on sexing young Bali Starling based on its morphological characters. 
Table 1. The sex of Bali Starling based on morphological assessment and molecular test

\begin{tabular}{|c|c|c|c|c|}
\hline \multirow{3}{*}{ No } & \multirow{3}{*}{$\begin{array}{c}\text { Sample } \\
\text { code }\end{array}$} & \multicolumn{3}{|c|}{ Bird sex based on } \\
\hline & & \multirow{2}{*}{ Morphology } & \multicolumn{2}{|c|}{ Molecular } \\
\hline & & & P2/P8 & 2550F/2718R. \\
\hline 1. & TNBB 0483 & 우 & $\sigma^{\pi}$ & $\sigma^{\pi}$ \\
\hline 2. & TNBB 0488 & $\sigma^{2}$ & 우 & - \\
\hline 3. & TNBB 0061 & 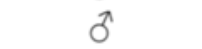 & 우 & 우 \\
\hline 4. & TNBB 0484 & $\sigma^{2}$ & $\delta$ & $\sigma^{2}$ \\
\hline 5. & TNBB 0302 & $\sigma^{n}$ & $\sigma^{n}$ & $\sigma^{n}$ \\
\hline 6. & TNBB 0134 & $\sigma^{2}$ & $\sigma^{2}$ & $\sigma^{\pi}$ \\
\hline 7. & TNBB 0029 & 우 & 우 & 우 \\
\hline 8. & TNBB 0900 & $\sigma^{2}$ & $\sigma^{2}$ & $\delta^{2}$ \\
\hline 9. & - & 우 & के & $\sigma^{n}$ \\
\hline 10. & TNBB 0037 & 우 & $\delta$ & 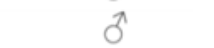 \\
\hline 11. & TNBB 0056 & 우 & 우 & 우 \\
\hline 12. & TNBB 0296 & $\sigma^{\prime}$ & o & - \\
\hline 13. & TNBB 0323 & 우 & 우 & 우 \\
\hline 14. & TNBB 0336 & $\hat{\sigma}$ & $\hat{\sigma}$ & $\sigma^{2}$ \\
\hline 15. & TNBB 0381 & Q & Q & - \\
\hline 16. & TNBB 0107 & $\sigma^{2}$ & $\sigma^{2}$ & $\sigma^{\pi}$ \\
\hline 17. & TNBB 0398 & $\hat{\sigma}$ & $\hat{\sigma}$ & $\delta$ \\
\hline 18. & TNBB 0146 & 우 & Q & 우 \\
\hline 19. & TNBB 0337 & 우 & 우 & 우 \\
\hline 20. & TNBB 0368 & $\widehat{\partial}$ & $\sigma^{2}$ & $\delta$ \\
\hline 21. & TNBB 0131 & 우 & के & $\sigma^{2}$ \\
\hline 22. & TNBB 0301 & 우 & 우 & 우 \\
\hline 23. & TNBB 0415 & $\widehat{\sigma}$ & $\widehat{\sigma}$ & $\widehat{\delta}$ \\
\hline 24. & TNBB 0405 & 우 & 우 & 우 \\
\hline 25 . & TNBB 0211 & $\sigma^{2}$ & ठั & ठ \\
\hline 26. & TNBB 0491 & 우 & 우 & - \\
\hline 27. & - & 우 & 우 & q \\
\hline 28. & TNBB 0399 & $\sigma^{2}$ & - & ठ \\
\hline 29. & TNBB 0419 & $\sigma^{\pi}$ & - & $\delta$ \\
\hline 30. & TNBB 0420 & 우 & - & 오 \\
\hline
\end{tabular}

\section{ACKNOWLEDGMENTS}

We thanks to the Head of Bali Barat National Parks for the permission for DNA sampling. This research received fund from DIKTI.

\section{REFERENCES}

BirdLife International. 2013. Species factsheet: Leucopsar rothschildi. .

Dawson, D. A., S. Darby, F. M. Hunter, and A. P. Krupa. 2001. A critique of avian CHD-based molecular sexing protocols illustrated by a Z-chromosome polymorphism detected in auklets. Molecular Ecology Notes 1:201-204.

Dubiec, A. and Z.-N. M. 2006. Molecular Techniques For Sex Identification In Birds. Biological Letters 200643 (1): 3.12. 43:3-12.

Fridolfsson, A.K., and H. Ellegren. 1999. A simple and universal method for molecular sexing of non-ratite birds. Journal of Avian Biology 30:116-121.

Griffiths, R., M. C. Double, K. Orr, and R.J.G. Dawson. 1998. A DNA test to sex most birds. Molecular Ecology 7:1071-1075. 
Kahn, N. W., J. S. John, and T. W. Quinn. 1998. Chromosome-Specific Intron Size Differences in the Avian CHD Gene Provide an Efficient Method for Sex Identification in Birds. The Auk 115:1074-1078. 